\title{
FAKTOR YANG MEMPENGARUHI KEPUTUSAN INVESTASI GENERASI MILENIAL PADA PRODUK SYARIAH DI PASAR MODAL
}

\author{
Windiya Saputri ${ }^{1} \&$ Nurwahidin ${ }^{2}$ \\ ${ }^{1 \& 2}$ Kajian Timur Tengah dan Islam, Sekolah Kajian Strategik dan Global, Universitas \\ Indonesia \\ Email:windiya.saputri@ui.ac.id,nurwahidin@ui.ac.id
}

\begin{abstract}
ABSTRAK
Generasi milenial adalah target potensial bagi pasar modal. Karakter tertentu yang dimiliki oleh golongan investor ini mempengaruhi keputusan investasi mereka di pasar modal. Penelitian ini bertujuan untuk menganalisa faktor yang mempengaruhi keputusan investasi generasi milenial dengan kriteria tertentu dalam pembelian produk syariah di pasar modal, baik saham syariah, rekasadana syariah, maupun sukuk. Penelitian ini menggunakan variabel return, atribut syariah, dan jenis kelamin sebagai variabel yang digunakan untuk mengukur keputusan investasi milenial terhadap produkproduk syariah di pasar modal. Teknik analisa data yang digunakan dalam penelitian ini adalah regresi linier berganda. Berdasarkan pengujian yang dilakukan, diperoleh hasil bahwa secara parsial, hanya variabel return yang berpengaruh signifikan terhadap keputusan investasi, sedangkan dua variabel lainnya yaitu atribut syariah dan jenis kelamin berpengaruh tidak signifikan terhadap keputusan investasi. Pengujian secara simultan juga dilakukan dan diperoleh hasil bahwa secara simultan return, atribut syariah, dan jenis kelamin berpengaruh signifikan terhadap keputusan investasi. Berdasarkan nilai $\mathrm{R}^{2}$, model dalam penelitian ini terlihat cukup baik, dimana variabel return, atribut syariah, dan jenis kelamin berkontibusi sebesar 46,7\% dalam menjelaskan variasi variabel keputusan investasi milenial di pasar modal. Pengembangan penelitian berikutnya dapat dilakukan dengan menambah jumlah variabel independen dan jumlah sampel dalam penelitian untuk hasil yang lebih baik.
\end{abstract}

Kata Kunci: Keputusan Investasi, Generasi Milenial, Produk Syariah.

\begin{abstract}
Millenials are pottential buyer in stock market. Particular characteristics inherent with this type of investor influence their investment decision in capital market. This study aims to analyze factors influencing millenial's investment decision on purchasing sharia products in capital market, including stocks, mutual funds, or sukuk. This research used sharia attributes, return, and gender as independent variables to measure millenial's investment decision. Multiple regressions are used to analyze the relationship of tested variables. The result shows that partially, perception on return is the only variable that significantly influenced investment decision. Meanwhile, both sharia attributes and gender have no significant influence in investment decision. Simultaneous testing is also carried out and the result obtained that return, sharia atibutes, and gender had significant effect on investment decisions. Based on $R^{2}$ value, the model looks quite good, showed by $R^{2}$ value of $46,1 \%$ which means return, sharia attributes, and gender contribute $46,7 \%$ in describing their variations in influencing millennial investment decisions. Future research is expected to increase the type of independent variables and the number of samples to achieve better result.
\end{abstract}

Keywords: Investent Decisions, Millennials Generation, Sharia Products. 


\section{PENDAHULUAN}

Globalisasi memberikan kesempatan kepada sebagian besar pasar konsumen untuk berinovasi dan menawarkan produkproduknya, termasuk salah satunya adalah pasar modal. Industri keuangan Islam terutama yang ada di pasar modal juga dituntut untuk terus berinovasi. Hal ini dapat ditunjukkan dengan banyaknya pilihan produk syariah di pasar modal, seperti saham syariah dan sukuk yang secara simultan menunjukkan perkembangan yang signifikan. Hal ini dapat ditunjukkan dari nilai kapitalisasinya pada tahun 2018 telah mencapai 591 milyar dollar secara global (Islamic Financial Service Board, 2019) dan 967 juta dolar pada tahun 2019 di Indonesia.

Kenaikan ini dipengaruhi oleh tren konsumsi masyarakat untuk produk halal yang meningkat. Tren konsumsi produk halal ini juga mencakup dunia pasar modal. Peningkatan ini dipengaruhi oleh gaya hidup yang baru di masyarakat, dimana konsumen saat ini lebih sadar terhadap apa yang mereka konsumsi. Dengan demikian, konsumsi produk halal tidak hanya mengarah pada kebutuhan untuk memenuhi kepatuhan syariah, tetapi termasuk dalam ranah untuk memenuhi kebutuhan gaya hidup, bahkan merupakan simbol yang dapat mengukur kualitas dan keyakinan (Rahim, 2016).

Konsumsi produk halal di pasar modal ini termasuk pada kegiatan konsumsi yang manfaatnya baru dapat dirasakan di masa depan. Orang yang telah dapat memenuhi kebutuhan pokoknya cenderung untuk melakukan kegiatan investasi dengan tujuan untuk mendapatkan pengembalian dan nilai tambah di masa depan. Produk Syariah di pasar modal memberikan alternatif bagi investor sebagai pilihan dari investasinya. Dua jenis produk di pasar modal yang cukup menarik minat investor di antaranya adalah saham syariah dan sukuk.

Saham dapat dikatakan sebagai saham syariah ketika saham tersebut memenuhi filter yang diberlakukan oleh aturan syariah sedangkan sukuk memiliki ciri pembeda dari obligasi, yaitu harus ada underlying asset yang menyertainya.

Terdapat beberapa faktor yang mempengaruhi investor untuk menentukan keputusannya berinvestasi di pasar modal. Selain faktor fundamental, teknikal, dan faktor yang berkaitan dengan pengumuman (dividen, laba, stock split, pengumuman yang berkaitan dengan pemerintah, dan lain-lain) investor dalam membeli produk di pasar modal juga dipengaruhi oleh faktor-faktor psikologis. Penelitian yang dilakukan oleh Abdul (2017), yang menyatakan bahwa faktor psikologi seperti herd behaviour (perilaku kawanan), optimisme, pesimisme dan resiko mempengaruhi keputusan pembelian investor di pasar modal.

Sedangkan Al-Tamimi (2006), dengan penelitian yang dilakukannya mengungkapkan bahwa faktor yang paling mempengaruhi keputusan pembelian produk di pasar modal adalah pendapatan yang diharapkan, memperoleh pendapatan dengan cepat, stock marketability, kinerja saham di masa lalu, government holdings, dan pasar keuangan yang terorganisir.

Investor di pasar modal Indonesia memiliki sebaran yang cukup menarik di sisi demografi. Investor di pasar modal Indonesia ternyata didominasi oleh generasi milenial. Dikutip dari Tempo tahun 2020 Bursa Efek Indonesia (BEI) pada akhir tahun 2019 menyatakan bahwa sebanyak 44,62 \% investor di pasar modal Indonesia berada di rentang usia di bawah 30 tahun dengan kontribusi asset sebesar Rp. 12,42 triliun. Sedangkan investor pada rentang usia 31-40 tahun berkontibusi sebanyak $24,44 \%$ dengan kontribusi asset sebesar Rp. 32,13 triliun dan investor usia 41 tahun ke atas menempati posisi minoritas, meskipun aset mereka tercatat paling besar.

Usia yang merupakan bagian dari kriteria demografi adalah salah satu kajian dalam teori perilaku konsumen. Usia atau generasi suatu kelompok memiliki karakter konsumsi yang berbeda dan unik jika dibandingkan dengan usia atau generasi 
lainnya. Pertimbangan terhadap variabelvariabel tertentu dapat dilakukan oleh investor dengan usia muda dalam mempengaruhi keputusan yang dibuat. Hal ini dipengaruhi oleh minimnya pengalaman yang mereka miliki. Di sisi lain, pertimbangan terhadap variabel-variabel tertentu tidak diperlukan bagi investor usia matang, yaitu pada usia tersebut pengambilan keputusan lebih banyak didasarkan pada logika (Utami dan Kartini, 2016).

Milenial dipandang sebagai generasi yang memperoleh Pendidikan dengan baik dan dekat dengan teknologi. Akan tetapi, terkait dengan keuangan, milenial cenderung tidak lebih bisa menyimpan uang dibanding dengan generasi sebelumnya, yaitu baby boomers (Frey, 2018). Kontradiksi ini menarik untuk dipelajari lebih lanjut, yaitu terkait dengan keputusan investasi milenial di pasar modal.

Milenial adalah target potensial bagi pasar modal. Pasar modal yang sarat akan kecepatan informasi dengan memanfaatkan kemajuan teknologi di bidang keuangan memiliki platform yang cocok bagi karakteristik milenial dengan mobilitas yang tinggi.

Penelitian yang berkaitan dengan keputusan investasi di pasar modal telah dilakukan oleh (Yuliati, 2011) dengan menggunakan variabel risiko investasi dan atribut Islami sebagai variabel yang mempengaruhi keputusan pembelian sukuk. Mudrikah (2018) juga melakukan penelitian sejenis tentang pengaruh return terhadap keputusan pembelian saham syariah dengan variabel Pendidikan sebagai variabel moderasi. Penelitian serupa juga dilakukan oleh Putri dan Isbanah (2018), yaitu untuk mengetahui faktor-faktor yang mempengaruhi keputusan investasi, yang salah satunya menggunakan variabel jenis kelamin. Berdasarkan hal-hal tersebut di atas, maka penelitian tentang keputusan pembelian generasi milenial di Indonesia pada produk-produk syariah di pasar modal akan diperhitungkan dengan menggunakan variabel return, atribut syariah, dan jenis kelamin.

\section{TINJAUAN PUSTAKA}

\section{Investasi Islami}

Investasi dapat diartikan sebagai penundaan konsumsi saat ini, yaitu dengan memproduktifkan harta untuk konsumsi di masa yang akan datang (Hartono, 2019). Seiring dengan berkembangnya inovasi produk investasi, semakin banyak pula pilihan produk bagi investor. Islam sebagai agama yang universal, memandang investasi sebagai sebuah anjuran, sebagaimana firman Allah SWT dalam Al-Qur'an surat Yusuf Ayat 46-50 yang mengandung perintah Allah SWT untuk tidak serta merta menghabiskan apa yang kita peroleh saat ini, akan tetapi menyimpannya atau memanfaatkannya untuk kebutuhan di masa depan. Hal ini berarti investasi adalah bukan larangan dalam Islam, asalkan harus sesuai dengan pedoman syariah, yaitu setidaknya investasi tidak mengandung unsur riba, maysir, gharar, zalim, dan haram.

Sukuk, saham syariah, reksadana syariah adalah beberapa contoh produk syariah di pasar modal yang dapat menjadi alternatif investasi bagi investor Muslim. Produk-produk ini telah memenuhi filter syariah, sebagaimana aturan yang telah ditetapkan oleh Dewan Syariah Nasional Majelis Ulama Indonesia (DSN-MUI) melalui fatwanya mengenai produk Syariah di pasar modal.

\section{Generasi Milenial}

Investor di pasar modal diwarnai dengan banyak karakteristik investor, sekaligus beragam tujuannya. Seperti misalnya di Indonesia, menurut data Kustodian Sentral Efek Indonesia (KSEI) 91\% pemodal adalah berasal dari generasi milenial yang berusia antara 20-40 tahun. Hal ini menunjukkan bahwa adanya potensi yang besar dari generasi milenial dalam ketertarikannya untuk investasi di pasar modal. Ketertarikan ini juga disebabkan karena faktor digitalisasi produk di pasar 
modal yang sangat dekat dengan generasi milenial. Menurut Smith dan Nichols (2015) milenial menikmati keberadaan teknologi dan menjadi tergantung pada hal tersebut daripada generasi-generasi sebelumnya.

Milenial adalah generasi yang bisa dibilang unik. Dalam banyak bidang, milenial dinilai memainkan perannya masing-masing serta memiliki karakteristik tersendiri dalam menyalurkan kontribusinya. Menurut Kaifi dalam Smith dan Nichols (2015) milenial adalah individu yang lahir antara tahun 1980-2000. Mereka disebut sebagai milenial karena mereka dibesarkan pada era digitalisasi.

Karakter milenial tersebut menjadi faktor penting yang harus diperhatikan dalam memperhitungkan keputusan investasi. Secara umum, Agustin dan Mawardi (2014) melakukan penelitian dengan metode kualitatif mengenai perilaku investor muslim dalam bertransaksi saham di pasar modal. Berdasarkan penelitian yang dilakukan dengan membuat perbedaan mendasar, yaitu investor yang mendasarkan keputusan investasinya kepada agama dan investor yang tidak mendasarkan keputusan investasinya kepada agama menghasilkan sebuah fakta bahwa keduanya mempertimbangkan aspek rasionalitas dan faktor psikologis.

\section{METODE PENELITIAN}

\section{Teknik Pengumpulan Data}

Metode penelitian yang digunakan dalam penelitian ini adalah kuantitatif. Populasi dalam penelitian ini adalah investor milenial di Indonesia. Sampel dalam penelitian ini adalah generasi milenial yang melakukan investasi di pasar modal dengan membeli saham syariah, sukuk, atau reksadana syariah. Adapun lingkup sampel pada penelitian ini adalah Milenial di Program Studi Kajian Wilayah Timur Tengah dan Islam Universitas Indonesia.
Data yang digunakan pada penelitian ini adalah data primer. Data primer diperoleh dari sumber data secara langsung. Dalam hal ini data diperoleh dari kuesioner yang disebarkan kepada sampel yang mewakili populasi.

\section{Teknik Analisis Data}

\section{Uji Asumsi Klasik}

Uji asumsi klasik yang akan dilakukan yaitu:

1. Uji Multikolinearitas

Interpretasi dari persamaan regresi linier berganda secara implisit bergantung pada asumsi bahwa variabel-variabel bebas dalam persamaan tersebut tidak saling berkorelasi (Chatterjee and Price dalam Nachrowi dan Hardius, 2008). Multikolinearitas diukur dengan nilai Varians Inflation Factor (VIF). Apabila nilai VIF $<5$ maka model bebas dari multikolinearitas.

2. Uji Heteroskedastisitas

Uji heteroskedastisitas dilakukan untuk memastikan model dalam variansi yang sama. Uji ini dilakukan dengan melihat grafik hasil uji heteroskedastisitas, yaitu apabila pola tergambarkan dengan sistematis, maka ada masalah hetereskedastisitas, dan begitupun sebaliknya.

\section{Uji Analisis Regresi Linier Berganda}

Uji analisis regresi linier berganda dilakukan untuk melihat pengaruh beberapa variabel terikat terhadap variabel bebas. Variabel yang digunakan dalam penelitian ini adalah return (X1), atribut syariah (X2), dan jenis kelamin (X3), serta keputusan investasi (Y). Adapun model regresi linier berganda yang disusun adalah: 


\section{Gambar 1. Model Regresi}

Keputusan Investasi $_{i}=\beta 0+\beta 1$ Return $_{\mathrm{i}}+\beta 2$ Atribut Syariah $_{\mathrm{i}}+\beta 3$ Jenis Kelamin $_{\mathrm{i}}+$ vi

Sumber : Data Olahan (2021)

\section{Uji Hipotesis}

Uji hipotesis dilakukan untuk meneliti pengaruh variabel bebas yang terdiri dari return, atribut syariah, dan jenis kelamin terhadap variabel terikat yaitu keputusan investasi.

1. Uji Signifikansi Parameter Individual (Uji-t).
2. Uji Signifikansi Simultan (Uji Statistik F).

\section{HASIL DAN PEMBAHASAN}

Uji Asumsi Klasik

1. Uji Multikolinearitas

Tabel 1. Hasil Uji Multikolinearitas

\begin{tabular}{|c|c|c|c|c|c|c|c|c|}
\hline \multirow{2}{*}{\multicolumn{2}{|c|}{ Model }} & \multicolumn{2}{|c|}{$\begin{array}{l}\text { Unstandardized } \\
\text { Coefficients }\end{array}$} & \multirow{2}{*}{$\begin{array}{l}\text { Standardized } \\
\text { Coefficients } \\
\text { Beta }\end{array}$} & \multirow[b]{2}{*}{$\mathbf{t}$} & \multirow[b]{2}{*}{ Sig. } & \multicolumn{2}{|c|}{$\begin{array}{l}\text { Collinearity } \\
\text { Statistics }\end{array}$} \\
\hline & & $\mathbf{B}$ & Std. Error & & & & Tolerance & VIF \\
\hline \multirow[t]{4}{*}{1} & (Constant) & 6.158 & 3.238 & & 1.902 & .068 & & \\
\hline & $J K$ & .279 & .518 & .080 & .538 & .595 & .904 & 1.106 \\
\hline & Return & .611 & .141 & .637 & 4.329 & .000 & .911 & 1.098 \\
\hline & Atribut_Syariah & .052 & .086 & .087 & .606 & .550 & .963 & 1.038 \\
\hline
\end{tabular}

Sumber : Data Olahan (2021)

Tabel di atas menunjukkan bahwa hasil varians inflation factor untuk melihat apakah ada gejala multikolinearitas pada model. Berdasarkan nilai varians inflation factor pada masing-masing jenis variabel bebas, diketahui bahwa model telah lolos uji multikolinearitas, karena nilai VIF dari masing-masing variabel terikat adalah kurang dari 5, yaitu return sebesar 1,106, atribut syariah sebesar 1,098, dan jenis kelamin sebesar 1,038. Sehingga, model telah dinyatakan lolos uji multikolinearitas.

\section{Uji Heteroskedastisitas}

\section{Gambar 2. Hasil Uji Heteroskedastisitas}

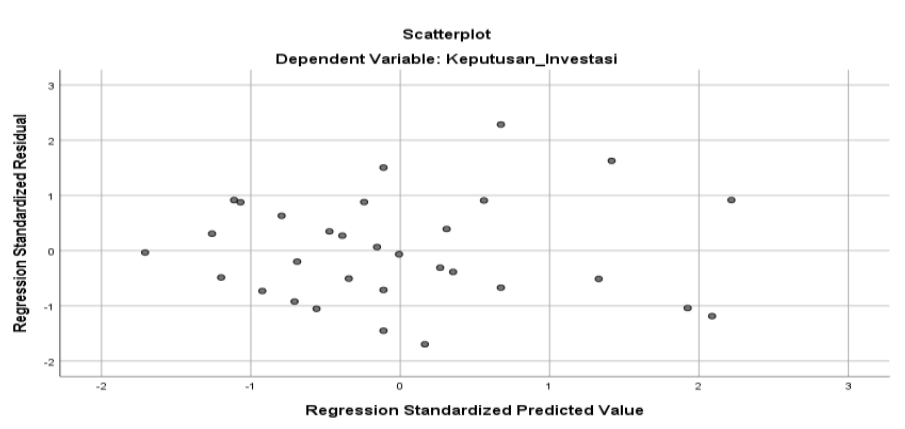

Sumber : Data Olahan (2021)

Gambar di atas menunjukkan bahwa data tersebar dengan tidak sistematis, dimana titik-titik menyebar secara acak, sehingga dapat disimpulkan bahwa error varian konstan atau homoskedastisitas.

\section{Uji Regresi Linier Berganda}

\section{Gambar 3. Model Regresi yang Terbentuk}

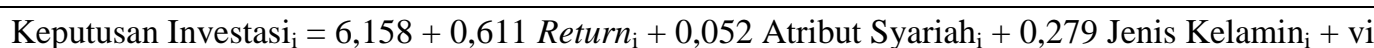


2021, Jurnal Tabarru' : Islamic Banking and Finance 4 (2) : 423 - 430

Gambar di atas adalah model yang terbentuk atas pengujian yang telah dilakukan. Berdasarkan model di atas, interpretasi yang didapat adalah sebagai berikut:

1. Intercept sebesar 6,158 artinya ketika return rendah, investor tidak mempertimbangkan atribut syariah, dan tidak ada pertimbangan jenis kelamin maka rata-rata nilai keputusan investasi adalah 6,158.

2. Setiap kenaikan return sebesar 1 satuan, maka keputusan investasi akan meningkat sebesar 0,611 satuan, cateris paribus.

3. Setiap kenaikan atribut syariah sebesar 1 satuan, maka kemungkinan keputusan investasi akan bertambah sebesar 0,0052 satuan.

4. Ketika yang berinvestasi adalah laki-laki (Jenis kelamin=1) maka rata-rata keputusan investasi adalah sebesar $(6,158+0,279=6,437$ satuan), cateris paribus. Ketika yang berinvestasi adalah perempuan (jenis kelamin =0) maka rata-rata keputusan investasi adalah sebesar 0,279 satuan, cateris paribus.

\section{Uji Hipotesis}

\section{Uji Signifikansi Individu (Uji-t)}

Uji pada masing-masing variabel terikat berdasarkan pada tabel 4.1 dinyatakan sebagai berikut:

a. Variabel return:

$\mathrm{H} 01: \beta 1=0$
H11 : $\beta 1 \neq 0$

Keputusan: Tolak H0 pada tingkat signifikansi 5\% (0,05). Kesimpulan: variabel return berpengaruh dignifikan terhadap variabel keputusan investasi (nilai signifikansi $<0,05$ yaitu sebesar 0 ).

b. Variabel atribut syariah:

$\mathrm{H} 02: \beta 2=0$

$\mathrm{H} 12: \beta 2 \neq 0$

Keputusan: Terima H0 pada tingkat signifikansi 5\% (0,05). Kesimpulan: variabel atribut syariah berpengaruh tidak dignifikan terhadap variabel keputusan investasi (nilai signifikansi $>0,05$ yaitu sebesar 0,55 ).

c. Variabel jenis kelamin:

$\mathrm{H} 0: \beta 3=0$

$\mathrm{H} 1: \beta 3 \neq 0$

Keputusan: Terima H0 pada tingkat signifikansi $5 \%(0,05)$. Kesimpulan: variabel jenis kelamin berpengaruh tidak dignifikan terhadap variabel keputusan investasi (nilai signifikansi $>0,05$ yaitu sebesar 0,595).

\section{Uji Signifikansi Simultan (Uji-F)}

Uji-F dilakukan untuk melihat pengaruh variabel return, atribut syariah, dan jenis kelamin secara bersama-sama terhadap keputusan investasi. Hasil yang didapat adalah sebagai berikut:

Tabel 2. Hasil Uji-F

\begin{tabular}{lllllll}
\hline Model & & Sum of Squares & Df & Mean Square & F & Sig. \\
\hline 1 & Regression & 43.269 & 3 & 14.423 & 7.877 & $.001^{\mathrm{b}}$ \\
\cline { 2 - 6 } & Residual & 49.440 & 27 & 1.831 & \\
\cline { 2 - 6 } & Total & 92.710 & 30 & & & \\
\hline
\end{tabular}

Sumber : Data Olahan (2021)

Berdasarkan output di atas, nilai signifikansi dari output anova adalah sebesar $0,001(<5 \%)$. Maka artinya, return, atribut syariah, dan jenis kelamin secara simultan berpengaruh signifikan terhadap keputusan investasi. 


\section{Koefisien Determinasi $\left(\mathbf{R}^{2}\right)$}

Variabel bebas (return, atribut syariah, dan jenis kelamin) mempunyai kontribusi untuk menjelaskan variasi variable ROA sebesar $46,7 \%$ dan sisanya dijelaskan variabel lain yang tidak diperhitungkan di dalam model.

Tabel 3. Koefisien Determinasi

\begin{tabular}{lllll}
\hline Model & $\mathbf{R}$ & R Square & Adjusted R Square & Std. Error of the Estimate \\
\hline 1 & $.683^{a}$ & .467 & .407 & 1.353 \\
\hline \multicolumn{4}{c}{ Sumber : Data Olahan (2021) }
\end{tabular}

\section{PEMBAHASAN}

Variabel return adalah satu-satunya variabel yang memiliki pengaruh signifikan terhadap keputusan investasi. Perihal ini sesuai dengan penelitian yang dilakukan oleh Mudrikah (2018) dan Malik (2017). Dengan pertanyaan yang diberikan, investor milenial pada penelitian ini diketahui mempertimbangkan aspek pendapatan sebagai faktor untuk menentukan keputusan investasi mereka.

Investor milenial cukup rasional dalam mementukan keputusan investasinya, yaitu dengan tujuan untuk mengharapkan keuntungan dengan berinvestasi pada produk Syariah di pasar modal. Return menjadi faktor yang penting bagi investor milenial dalam mempengaruhi keputusan Investasi mereka. Hal ini juga dipengaruhi oleh kriteria dari investor milenial yang masih baru dan belum memiliki banyak pengalaman, sehingga setidaknya return menjadi faktor penentu yang penting dalam mempengaruhi keputusan investasi mereka.

Variabel Atribut Syariah berpengaruh
tidak signifikan terhadap Keputusan Investasi Investor Milenial. Perihal ini bertentangan dengan hasil penelitian yang dilakukan oleh Yuliati (2011) dan Al-Afifi (2014). Kemungkinan penyebab dari hasil yang tidak signifikan tersebut adalah jumlah sampel yang terlalu kecil, yaitu hanya 31 investor milenial atau berkaitan dengan karakteristik dari investor milenial yang menyebabkan mereka belum memandang atribut syariah sebagai suatu aspek yang penting dalam melakukan investasi pada produk syariah di pasar modal. Meskipun sebenarnya sebagian besar saham yang ada di pasar modal Indonesia adalah saham syariah.

Variabel jenis kelamin berpengaruh tidak signifikan terhadap keputusan investasi. Hasil tersebut sesuai dengan penelitian yang dilakukan oleh Putri dan Isbanah (2018). Dengan kata lain, penelitian ini menunjukkan bahwa jenis kelamin bukanlah faktor yang signifikan dalam mempengaruhi keputusan investasi investor milenial. Adapun faktor yang kemungkinan menjadi penyebabnya adalah karakteristik gender baik laki-laki maupun perempuan tidak begitu berbeda dalam kaitannya dengan perilaku investasi mereka di pasar modal.

\section{KESIMPULAN}

Berdasarkan penelitian yang dilakukan, diketahui bahwa hanya variabel return yang berpengaruh signifikan dalam mempengaruhi keputusan investasi generasi milenial, dibanding dua variabel lainnya, yaitu atribut syariah dan jenis kelamin. Model yang dibentuk sudah dapat dikatakan mewakili faktor yang mempengaruhi keputusan investasi milenial di pasar modal dengan nilai $\mathrm{R}^{2}$ sebesar $46,7 \%$.

\section{DAFTAR PUSTAKA}

Abdul, Sadeq. 2017. Factor Influencing Individual Investor Behaviour: Evidence from Kuwait Stock Exchange. Asian Social Science, 15(3), p. 27-39.

Agustin, Pramita., \& Mawardi, Imron. 2014. Perilaku Investor Muslim dalam Bertransaksi Saham di Pasar Modal. Jurnal Ekonomi Syariah Teori dan Terapan, 1(12), p. 874-892. 
Al-Afifi, Ahmed A.M. 2014. The Impact of: Financial Literacy, Religious Belief, Brokerage Firms on Palestinian Investor's Behaviour (Exploratory Study on The Individual Investor in Gaza Strip). Journal od Human and Sciences Al-Azhar University, 1(16), p. 1-34.

Al-Tamimi, Husein A. Hasan. 2006. Factors Influencing Individual Investor Behavior: An Empirical study of the UAE Financial Markets. Unpublished master's thesis, University of Sharjah, Sharjah, U.A.E.

Frey, William H. 2018. The Millennial Generation: a Demographic bridge to America's Diverse Future. Report, Brookings.

Hartono, Jogiyanto. 2019. Teori Portofolio dan Analisis Investasi. Edisi Keenam. BPFE. Yogyakarta.

Islamic Financial Service Board. 2019. Islamic Financial Service Industry Stability Report. Malaysia: Bank Negara Malaysia.

Malik, Ahmad Dahlan. 2017. Analisa Faktor-faktor yang Mempengaruhi Minat Masyarakat Berinvestasi di Pasar Modal Syariah Melalui Bursa Galeri UISI. Jurnal Ekonomi dan Bisnis Islam, 3(1), p. 61-84.

Mudrikah, Siti. 2018. Analisis Pengaruh Persepsi Return pada Keputusan Berinvestasi di Saham Syariah dengan Pengetahuan sebagai Variabel Moderasi. Skripsi. Fakultas Ekonomi dan Bisnis Islam Universitas Islam Negeri Walisongo. Semarang.

Nachrowi, Nachrowi Djalal., \& Hardius, Usman. 2008. Penggunaan Teknik Ekonometri. Jakarta. Raja Grafindo.

Putri, Ramadhani Anendy., \& Isbanah, Yuyun. 2018. Faktor-faktor yang Mempengaruhi Keputusan Investasi pada Investor Saham di Surabaya. Jurnal Ilmu Manajemen, 8(1), p. 197 209.
Rahim, N. 2016. Consumer Behaviour, Perception and Planning Towards Halal Marketing. in Mutum, D., Butt, M. and Rashid, M. (Ed.): Advances in Islamic Finance, Marketing, and Management: An Asian Perspective, p. 271-307.

Smith, Travis J. dan Tommy Nichols. 2015. Understanding the Millennial Generation. Journal of Business Diversity, 15(1), p. 39-47.

Yuliati, Lilis. 2011. Faktor-faktor yang Mempengaruhi Minat Masyarakat Berinvestasi Sukuk. Walisongo, 19(1), p. 103-126. 